\title{
Andrew Clements'in Bunun adı Findel adlı çocuk edebiyatı eserinin çocuğa görelik açısından incelenmesi
}

\section{Behice VARIŞOĞLU1}

\section{Şehnaz Hikmet TUZCUOĞLU AKSİN²}

\begin{abstract}
APA: Varışoğlu, B.; Tuzcuoğlu Aksin, Ş. H. (2019). Andrew Clements'in Bunun adı Findel adlı çocuk edebiyatı eserinin çocuğa görelik açısından incelenmesi. RumeliDE Dil ve Edebiyat Araştırmaları Dergisi, (16), 639-656. DOI: 10.29000/rumelide.619651
\end{abstract}

\section{$\ddot{\mathbf{O} z}$}

Çocuk kitapları, çocuk edebiyatının önemli gereçlerindendir. Çocuk kitap ile o-2 yaş arasında tanışır. Bu dönemin en belirleyici özelliği çocuk ve kitap arasındaki ilk bağın kurulmasıdır. Etkin bir uyaran olarak çocuğun yaşamına giren kitap aracılı̆̆ıyla çocuk işitsel, dilsel ve kültürel ögelerle tanışmaya başlar. Çocuğun erken yaşta kitap ile bağ kurması kadar önemli olan bir diğer öge çocuğu doğru ve gelişim dönemine uygun nitelikli kitaplarla buluşturmaktadır. Çocuğa görelik ilkesi gözetilerek hazırlanan kitaplar, çocuğun düzeyine ve yaşına uygun olmalıdır. Bu çalışmanın amacı Andrew Clements'in Bunun Adı Findel adlı çocuk edebiyatı eserinin çocuğa görelik açısından uygun olup olmadığını araştırmaktır. Nitel araştırma yöntemlerinden doküman incelemesi yöntemi ile elde edilen veriler tasartm, konu, ileti, karakter, dil ve anlatım, eğitsel ilkeler çerçevesinde incelenmiştir. Araştırmanın öne çıkan sonuçları şunlardır: Kitabın içerik ve dış kapak tasarımındaki görsel ve dilsel unsurların çocuğa görelik açısından uygun olduğu, resimlerin çocukların konu hakkında betimleme yapmalarına yardımcı olacak şekilde çizildiği; kitapta yer alan olayların çocukların gülmesine, heyecanlanmasına, düş kurmasına ve düşünmesine olanak sağladığı, kitapta sık sık kurallar sorgulandı̆̆ı için eleştirel düşünmenin ve yaratıcılık temalarının işlendiği; kitapta yer alan kahramanların çocuğun sevgi ve güven ihtiyacına yanıt verebilecek özellikte olduğu; kitapta karakter ve olay betimlemelerinde deyimlere, sıfat ve isim tamlamalarına ve ikilemelere çokça yer verildiği tespit edilmiştir.

Anahtar kelimeler: Andrew Clements, Bunun Adı Findel, çocuk edebiyatı, çocuğa görelik.

\section{An investigation of Andrew Clements novel in the name of Frindle in terms of suitability for children}

\begin{abstract}
Children's books are important instruments of children's literature. A child meets the book between the ages of 0-2. The most decisive feature of this period is the establishment of the first link between the child and the book. Through the book that enters the child's life as an effective stimulus, the child begins to become familiar with auditory, linguistic and cultural elements. Another element that is as important as the child's bonding with the book at an early age brings the child to the right and suitable books for the period of development. Books prepared in accordance with the principle of suitable for the child should be appropriate to the level and age of the child. The purpose of this study is to

1 Doç. Dr., Tokat Gaziosmanpaşa Üniversitesi, Eğitim Fakültesi, Türkçe ve Sosyal Bilimler Eğitimi Bölümü, Türkçe Eğitimi ABD (Tokat, Türkiye), bvarisoglu@hotmail.com, ORCID ID: 00oo-0003-4172-7081 [Makale kaylt tarihi: 22.06.2019kabul tarihi: 20.09.2019; DOI: 10.29000/rumelide.619651]

2 YL Öğrencisi, Tokat Gaziosmanpaşa Üniversitesi, Eğitim Bilimleri Enstitüsü, Türkçe Eğitimi ABD (Tokat, Türkiye),
\end{abstract} sehnazhikmet@gmail.com, ORCID ID: oooo-00o3-3420-336X 
An investigation of Andrew Clements novel in the name of Frindle in terms of suitability for children / B. Varışoğlu, Ş. H. Tuzcuoğlu Aksin (p. 639-656)

\begin{abstract}
investigate whether Andrew Clements novel, which is named as Frindle, is suitable for children. In this study, which examined a book in terms of the basic elements of children's literature, the principles of qualitative research method were followed. The data were obtained by using document analysis method which is one of the qualitative research methods and examined within the framework of design, subject, message, character, language and expression, educational principles. The results of the research are as follows: the visual and linguistic elements of the book's content and cover design are appropriate for children. The pictures are drawn to help children to describe the subject. The events in the book allow children to laugh, excite, dream and think. Critical thinking and creativity themes are covered in the book because the rules are frequently questioned in the text. The characters in the book are appropriate for the child's need for love and trust. Idioms, adjective and noun phrases, and dilemmas are widely used in character and event descriptions.
\end{abstract}

Keywords: Andrew Clements, Frindle, children's literature, suitability for children.

\title{
Giriş
}

Çocuk edebiyatının en önemli gereçleri çocuk kitaplarıdır. Okuma sevgisi, okuma alışkanlığı ve zamanla okuma kültürü kazandırmak nitelikli çocuk kitaplarının temel işlevlerinden biridir. Çocuğun nitelikli çocuk edebiyatı kitapları ile buluşturulması ve bir uyaran olarak çocuğun yaşam alanında kitabın yer almasını sağlamak için başta aile (anne-baba) olmak üzere, çocuğun içinde yaşadı̆̆ı çevrenin duyarlı bir çaba ile bilinçli katkılar vermesi gerekir (Aslan, 2013, s. 6; Sever, 2012, s. 19).

Çocuk ile kitap arasındaki ilk etkileşim okulöncesi dönemdedir. Çocuk kitap ile o-2 yaş arasında tanışır. $\mathrm{Bu}$ dönemin en belirleyici özelliği çocuk ve kitap arasındaki ilk bağın kurulmasıdır. Etkin bir uyaran olarak çocuğun yaşamına giren kitap aracılığıyla çocuk işitsel, dilsel ve kültür öğeleriyle tanışmaya başlar. Bu dönemden sonra ilköğretim döneminde kitap ile olan yakınlığı duyarlı bir çabayla desteklenen çocuklar, okuma kültürü edinme sürecinde somut yaşantılar edinmiş olur (İnce Samur, 2016, s. 39; Sever, 2013, s. 92).

Sever'e (2013, s. 9) göre okuma kültürü, "yazılı kültür ürünlerinin dünyasıyla tanışmış; tanıştı̆̆ bu dünyanın kendine sunduğu iletileri paylaşma, sınama, sorgulama yeterliğine ulaşmış; bunların sunduğu olanaklarla yaşamayı alışkanlık haline getirmiş bireylerin edinmiş olduğu kültürdür." Alanyazında daha çok okuma alışkanlığı olarak yer alan okuma kültürü, eleştirel okumayı da içine alan bir süreçtir. Okuma kültürü kavramını özlü bir belirlemeyle açılayan İnce Samur'a (2014, s. 159) göre "okuma kültürü okumanın eleştirel paydada yapılandırılması ve bu eylemin bireysel olmaktan çıkarılıp toplumsal düzlemde sistemli bir yapıya dönüştürülmesi sürecidir. Bu doğrultuda en etkili araç, nitelikli çocuk kitaplarıdır."

Oğuzkan'a (2001b, s. 11) göre okullarda okuma derslerinde öğretmenler yalnız okuma öğretmeyi hedef olarak ele almazlar, onlar aynı zamanda kitabı sevdirmek ve okuma arzusunu uyandırmak için de gerekli tedbirleri alırlar. Onlara ders kitaplarından başka kitaplar ve dergiler tavsiye ederler. Hatta bu maksatla sınıf ve okul kitaplıkları kurarlar. Onlara serbest ve müsait zamanlarda bu kitapları dağıtarak okuturlar. Ĕ̆er gerekirse evlerine götürmelerine, serbest zamanlarında evlerinde okumalarına müsaade ederler.

Çocukların kitap sevgisi ve okuma alışkanlığı kazanması adına kitap okumalarını tavsiye etmek yeterli değildir. Onları gelișim özelliklerine ve ilgilerine uygun kitaplara yöneltmek gerekir. Günümüzde çocuklara yönelik birçok kitap yayımlanmaktadır. Bu kitapların çokluğu nitelik konusunu da gündeme 
getirmektedir. Geleceği oluşturacak çocukların nitelikli eserlerle tanışması önemlidir. Ebeveyn ve öğretmenler bu amaçla, çocukları sadece klasik çocuk kitaplarıyla değil günümüzde yayımlanan nitelikli çocuk kitaplarıyla da tanıştırmalıdır (Tekin, 2017, s. 2).

Çocuğun erken yaşta kitap ile bağ kurması kadar önemli olan bir diğer öğe çocuğu doğru ve gelişim dönemine uygun nitelikli kitaplarla buluşturmaktadır. Çocuğa görelik ilkesi gözetilerek hazırlanan kitaplar, çocuğun düzeyine ve yaşına uygun olmalıdır. Çocuk okurun kendi dünyasında anlamlandıramadı̆̆ı bir kitap onu okuma eyleminden uzaklaştırabilir. Çocuk edebiyatı ürünleri, çocuk duyarlılığı gözetilerek "çocuğa görelik" ilkesiyle hazırlanmalıdır. Bu aşamada yazarın çocuksuluk ve çocuğa görelik kavramları arasındaki ayrımı iyi yapması gerekmektedir. Çocuksuluk, dilin acemice kullanımı, anlatımda ilkellik olarak görülmektedir. Çocuğa görelik ise, çocuğun ilgisini, gereksinimlerini, dil evrenini göz önünde bulundurmayı gerektirir (Sever, 2012). Şirin'e (2000, s. 19) göre "çocuğa göre deyince, çocuklar için yapılacak edebiyatın çocuğun büyüme ve gelişme çağlarına, psikolojisine, sözcük ve kavram ilgisine, algılama dünyasına uygun bir duyarlılık anlaşılmalıdır."

Nitelikli çocuk edebiyatı yapıtlarında bulunması gereken özellikler çocuk edebiyatı araştırmacıları tarafından belirli başlıklar altında ele alınmıştır. Aynı zamanda çocuk kitaplarında bulunması gereken bu özellikler, çocuk edebiyatının temel öğeleri olarak da adlandırılmıştır. Sever ve diğerlerine (2007, s. 41-56) göre nitelikli çocuk edebiyatı yapıtlarında bulunması gereken temel özellikler dış yapı (tasarım) ile ilgili özellikler; büyüklük, kâğıt, kapak-cilt, sayfa düzeni, harfler, resim, iç yapı ile ilgili özellikler; kahramanlar, konu, ileti, dil ve anlatım ve çocuk kitaplarında bulunması gereken temel eğitim ilkeleri olarak ele alınmaktadır.

Bu çalışmanın esas noktasını özellikle ortaokul öğrencilerinin okudukları edebi türler içinde yer tutan çocuk edebiyatı türünün başarılı örneklerini veren Andrew Clements'in eserlerinden eğitim-öğretimde yararlanılması gerektiğinin ortaya konulması oluşturmaktadır. Yapılan araştırmalarda, bu çalışmanın hareket noktası olan Andrew Clements'in çocuk kitaplarının Türkçe öğretimine katkısı konusunda hiçbir çalışmanın yapılmadığı görülmüştür.

\section{Araștırmanın amacı}

Bu araştırmanın amacı Andrew Clements'in Bunun Adı Findel adlı çocuk edebiyatı eseri çocuğa görelik açısından uygun mudur? sorusuna cevap aramaktır. Bu amaç doğrultusunda şu alt problemlere cevap aranmıştır:

1. Andrew Clements'in Bunun Adı Findel adlı çocuk edebiyatı eseri tasarım açısından çocuğa görelik ilkesine uygun mudur?

2. Andrew Clements'in Bunun Adı Findel adlı çocuk edebiyatı eseri konu açısından çocuğa görelik ilkesine uygun mudur?

3. Andrew Clements'in Bunun Adı Findel adlı çocuk edebiyatı eseri ileti açısından çocuğa görelik ilkesine uygun mudur?

4. Andrew Clements'in Bunun Adı Findel adlı çocuk edebiyatı eseri karakter çerçevesi açısından çocuğa görelik ilkesine uygun mudur? 
5. Andrew Clements'in Bunun Adı Findel adlı çocuk edebiyatı eseri dil ve anlatım açısından çocuğa görelik ilkesine uygun mudur?

6. Andrew Clements'in Bunun Adı Findel adlı çocuk edebiyatı eseri eğitsel ilkeler açısından çocuğa görelik ilkesine uygun mudur?

\section{Araştırmanın önemi}

Çocuk edebiyatı yapıtları, çocukların dil gelişimini destekleyen, onlara anadilinin kullanılışını, olanaklarını, yaratıcı gücünü sezinleten, anlama, yorumlama ve yeni anlamlar yaratma becerilerini kullanarak yaşamı ve insanı anlamaya yönelik deneyimler edinmelerini sağlayan yapıtlardır (Sever, 2013, s. 43).

Çocuk edebiyatı eserlerinin niteliği onları okuyan çocukların dünyasındaki etkisi açısından önemlidir. $\mathrm{Bu}$ sebeple çocuk edebiyatı eserlerinin, çocuğa görelik yönünden incelenmesi önemli olabilir. Alanyazında Andrew Clements'in çocuk kitaplarının, çocuğa görelik açısından incelenmesine ilişkin bir çalışma bulunmamaktadır. Bu açıdan bu çalışma, mevcut boşluğu tamamlaması ve ilgili alanyazına katkı sağlaması bakımından önemlidir. Bu çalışma ile çocuk kitaplarının edebi anlamda değerli olan ve çocuklara uygun olması açısından bunlardan daha fazla yararlanılması, öğrencilerin halihazırda okudukları basit, niteliksiz eserler yerine tercih edilebilecek daha nitelikli eserlere yönlendirilmesi sağlanabilir. Niteliksiz kitaplar hem çocuğun dünyasını olumsuz etkileyebilir hem de çocuğun kitapla ilişkisini zayıflatabilir. Bu çalışma ayrıca, ailelerin ve eğitimcilerin nitelikli çocuk kitapları belirleme ve seçmesine katkı sağlayabilir. Bu açıdan, Andrew Clements'in çocuk edebiyatı eserlerinden Bunun Adı Findel adlı eserinin biçimsel, içerik ve eğitsel özellikler açısından çocuğa görelik bağlamında incelenmiştir.

\section{Yöntem}

\section{Araştırma deseni}

Andrew Clements'in çocuk kitaplarının, çocuk edebiyatının temel ögeleri bakımından incelenmesine ilişkin yapılan bu çalışmada nitel araştırma yöntemlerinin ilkelerine uyulmuştur. Çalışmanın verilerini betimleyebilmek amacıyla nitel tarama modeli kullanılmıştır. Karasar'a (2009, s. 77) göre "Tarama modelleri, geçmişte olan ya da halen var olan bir durumu var olduğu şekliyle betimlemeyi amaçlayan araştırma yaklaşımlarıdır. Araştırmaya konu olan olay, birey ya da nesne, kendi koşulları içinde ve olduğu gibi tanımlanmaya çalışılır.". "Bu tür araştırmalar, daha çok 'ne, nerede, ne zaman, hangi sıklıkta, hangi düzeyde, nasıl' gibi soruların cevaplandırılmasına olanak tanır." (Büyüköztürk vd., 2013, s. 177). Bu nedenle, araştırmanın amacına uygun olarak Bunun Adı Findel adlı eser doküman incelemesi yoluyla incelenmiştir.

\section{Araştırmanın kapsamı}

Bu çalışmanın kapsamı, Andrew Clements'in çocuklar için yazdığı Brian Selznick tarafından resimlenen, toplam 112 sayfadan oluşan, Günışığı Kitaplığı tarafından Mart 2018'de 43. baskısı yapılan Bunun Adr Findel adlı çocuk edebiyatı kitabıyla sınırlıdır. Araştırmada elde edilen bulgular, bu kitap için geçerli olduğundan yazarın diğer eserleri için genelleme yapılmamıştır. 


\section{Verilerin toplanması ve analizi}

$\mathrm{Bu}$ çalışmada incelenen eserin çocuğa görelik açısından incelenmesi amacıyla doküman incelemesi yapılmıştır. Çocuğa görelik ilkelerinin neler olduğu konusundaki alanyazına ait çalışmalara (Karaca ve Temizyürek, 2017; Tekin, 2017; Arıkan, 2018; Kirazlı, 2018) ulaşılmıştır. Bu çalışmalarda ortak olarak yer alan çocuğa görelik ilkeleri tasarım, konu, ileti, karakter, dil ve anlatım, eğitsel ilkeler başlıkları altında toplanmıştır. Bunun Adı Findel adlı kitap belirlenen ilkeler doğrultusunda okunmuş, okumalar esnasında notlar tutulmuş, daha sonra bu notlar düzenlenerek yazıya geçirilmiştir.

\section{Bulgular}

Bu bölümde, Andrew Clements tarafından kaleme alınan, Bunun Adı Findel adlı çocuk edebiyatı eserinin çocuğa görelik açısından incelenmesine ilişkin bulgular sunulmuştur.

\section{Tasarıma ilişkin bulgular}

Araştırmada tasarım ilkesi büyüklük, kâğıt, kapak-cilt, sayfa düzeni, harfler ve resimleraçısından incelenmiştir.

\section{Büyüklük}

Kitap 12 x $18 \mathrm{~cm}$ boyutundadır. Bu boyutun ilköğretimin ilk yllarından itibaren çocukların kitaplık oluşturması ve düzen alışkanlıklarına katkı sağlaması bakımından uygun olduğu düşünülmektedir.

\section{Kâğıt}

Kitapta ikinci hamur kâğıt kullanılmıştır. Rengi tam olarak beyaz olmamakla birlikte kitap gibi ürünlerin baskısında fiyat avantajı nedeniyle bu kâğıt tercih edilmektedir. Bu kâğıdın çocuk edebiyatı yapitlarında kullanılması dayanıklılık açısından uygundur. Kitabın basımında kullanılan kâğıdın kalitesi, çocuğun kitabı uzun yıllar okuyabilmesine olanak sağlar niteliktedir. Ayrıca kullanılan kâğıt kitabın satış fiyatının uygun olmasını sağlamıştır.

\section{Kapak-cilt}

Kitapta sırt kısmı tutkalla yapıştırılmış cilt kullanılmıştır. Bu bakımdan sağlam ve dayanıklıdır. Kitabın adı ön kapakta beyaz zemin üzerine kırmızı renkle yazılmıştır. Arka kapakta ise kırmızı şerit zemin üzerine turuncu renkle yazılmıştır. Kitabın ön kapak resminde kaleme "Findel" adını veren baş kahraman Nick ve elinde tuttuğu siyah renkte pilot kaleme şaşkınlık, ilgi ve merakla bakan arkadaşları yer almaktadır. 


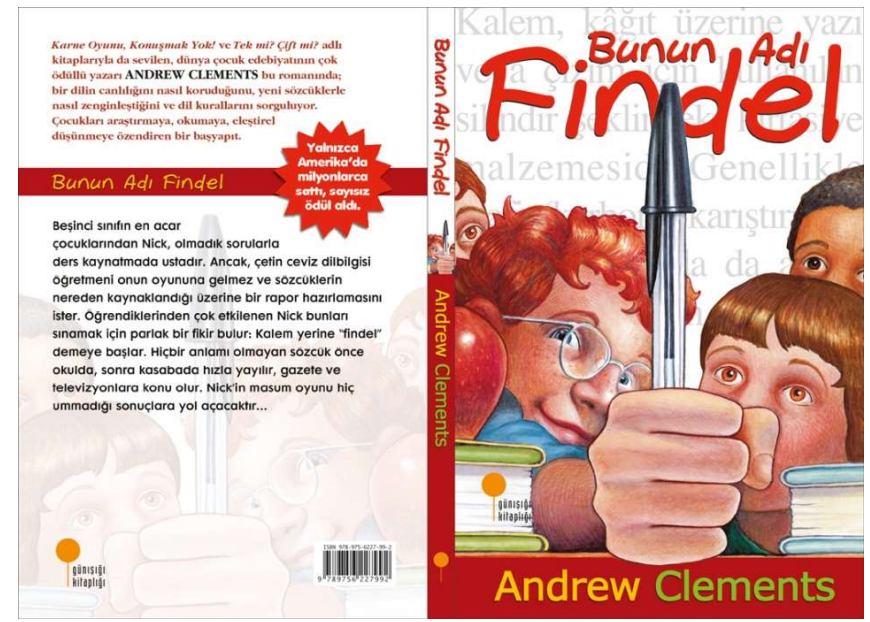

Resim 1. Bunun Adı Findel adlı eserin ön-arka dış kapağı

Arka kapak resminde ön kapak resminin saydam hali ve kitabın içeriği hakkında bilgi veren kısa bir tanıtım yazısı yer almaktadır. Kitabın ön ve arka kapak resimleri incelendiğinde kapak tasarımının çocukta merak duygusu uyandıran, ilgi çekici ve renkli olduğu görülmektedir.

\section{Harfler ve sayfa düzeni}

Çocuk kitaplarında resim-metin uyumu, sayfa kenarlarındaki boşluklar ve bunların sayfadaki diğer ögelerle birlikte yarattığı oransal uyum, sayfa düzenini sağlayan bileşenler olarak değerlendirilebilir. Yazar ve çizer tarafından kurgulanan içerik, yaş grubuna uygun yazı karakteri ve punto ile sunulmalı; harf, sözcük, satır arası, alt ve üst kenar boşlukları ile resim-metin uyumu, kitabın sayfalarında görsel bir bütünlük yaratmalıdır (Sever, 2012, s. 187-188). Bu çerçevede, incelenen kitabın sayfa düzeni, sayfa kenarlarındaki boşluklar, çocuğun kitabı rahat okuması bakımından uygun ve düzenlidir.

"İlköğretim 4. sınıf ve sonrası için hazırlanan kitaplarda (9-12 yaş üstü) 10-12 puntoluk harf karakterlerinin kullanılması hızlı okuyabilmeyi kolaylaştırmaktadır" (Şimşek, 2011, s. 92). İncelenen kitapta kullanılan harfler 12 puntodur. Bu boyut ilköğretim dördüncü sınıftan itibaren çocuk okurun düzeyine uygundur. Kitapta tırnaklı bir font kullanılmıştır. "Tırnaklı yazıların, harfler arasında oluşturduğu boşluk uzamsal bir gerilim yaratır. Böylece tırnaksız yazılara nispeten daha okunur yapıda bir boşluk düzeni oluşturulur." (Yıldız ve Keş, 2017, s. 2794). Bu nedenle tırnaklı fontun tercih edilmesi okunabilirliği kolaylaştırmıştır.

\section{Resim}

Çocuk kitaplarında resim, kendi başına görsel bir öge olarak önemli bir işlevi yerine getirdiği gibi, metinle birlikte düşünüldüğünde de anlamı tamamlayan, açıklayan, genişleten, bazen de metne yeni anlamlar katan estetik bir uyaran olur (Sever, 2012, s. 166). 112 sayfadan oluşan kitabın 11 sayfasında sadece görsel yer almaktadır. Kitabın toplam sayfa sayısına bakıldığında \%10'unun görsellerden oluştuğu söylenebilir. "Kitaplardaki resimlemeler, çocukların konuyu daha kolay kavramasına yardımcı olur. Yoğun bilgi içeren metinler barındıran ders kitaplarında illüstrasyon, fotoğraf, grafik düzenleme, tablo gibi görsel elemanlar hem kitabı estetik açıdan zenginleştirmekte ve güzelleştirmekte, hem de öğrencilerin dikkatini toplamalarına yardımcı olarak onları yönlendirmektedir. $\mathrm{Bu}$ sebeple 
resimlemelerin anlatım, teknik ve estetik açıdan yeterli olması gerekmektedir." (Mazlum ve Mazlum, 2016, s. 12). Bu kitapta da resimler yorumlama görevini yerine getirme veya anlatılan olayı gösterme açısından metni türlü yollardan açıklamaktadır.

Kitapta yer alan resimlerin incelenmesine ilişkin bazı belirlemeler şöyledir:

Resim 2. Bunun Adı Findel adlı kitaptan bir sayfa (s. 19)

Resim 2, Bayan Granger'in sözlük kullanma ve sözlüklere verdiği önemi anlatan bir görseldir. Metinde bu bölümde

\begin{abstract}
"Lincoln İlkokulunun bütün öğrencileri beşinci sınıfa ulaştıklarında yazım yanlışlarının, okuma becerilerinin,en kötüsü de sözcük bilgilerinin -haftalar, hatta aylar boyunca- Bayan Granger tarafindan değerlendirileceğini çok iyi biliyorlardı. Dünyadaki bütün dil bilgisi ve edebiyat öğretmenlerinin hepsi de öğrencilere sözlük kullandırmaya bayılırlar: "Yazımınız doğru mu kontrol edin. O sözcüğün karşıllğına bakın. Şu hece ayrımlarını denetleyin." Ama Bayan Granger sözlüğe bayılmak ne kelime, sözlüğe âşıktı -neredeyse ona tapıyordu. Ödev verdiği haftalık sözcük listesi en az otuz beş sözcükten oluşurdu... Bayan Granger sınıfin arka tarafindaki bir rafta tam takım otuz sözlük bulundururdu. Ama onun gözdesi ve övünç kaynağı, evrende ne kadar sözcük varsa içeren, ancak iki çocuğun birlikte taşıyabildiği o devasa sözlüklerden biriydi. Sinıfının ön tarafında sunak taşına benzeyen kendi küçük masası üzerinde dururdu bu dev sözlük." (s. 18-20)
\end{abstract}

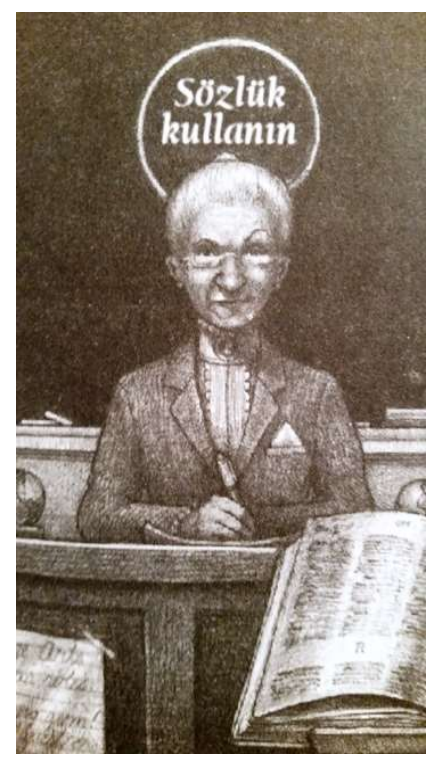

ifadeleriyle Bayan Granger'in sözlüğe verdiği önem aktarılmaktadır. Bu bakımdan resim 2, yazınsal iletiyi görsel ögelerle tamamlar nitelikte metin ile uyumludur. Kitapta yer alan resimler metin ile uyumlu, anlatılanları açıklar nitelikte ve salt siyah-beyaz renktedir.

Çocuk kitaplarında resim, kendi başına görsel bir öge olarak önemli bir işlevi yerine getirdiği gibi, metinle birlikte düşünüldüğünde de anlamı tamamlayan, açıklayan, genişleten, bazen de metne yeni anlamlar katan estetik bir uyaran olur (Sever, 2012, s. 166). İncelenen kitapta resimler metinle uyum içerisinde ve anlamsal olarak metinle ilişkilendirilmiştir. Görsellerin, metinde işlenen konu, olay, duygu, düşünce ve iletilerle ilgili olması metni anlama gücünü artırmaktadır.

\title{
2. Konuya ilişkin bulgular
}

Araştırmada incelenen kitap, beşinci sınıfın en acar çocuklarından Nick'in araştırdığı bir ödevden etkilenerek kalem sözcüğü yerine findel sözcüğünü bulması ve çetin ceviz dil bilgisi öğretmeniyle bu sözcük üzerine aralarında geçen masum oyunu konu edinir.

Nick olmadık sorularla tam bir ders kaynatma ustasıdır. Ancak dil bilgisi öğretmeni Bayan Granger için bu numaralar fayda etmez. Nick'in sorduğu soru, kendisine hazırlayacağı bir rapor olarak geri döner. Öğrendiklerinden çok etkilenen Nick bunları denemek için parlak bir fikir bulur. Kalem yerine findel demeye başlar. Ve arkadaşlarıyla birleşerek öğretmeniyle bir varlık mücadelesine girişir. Ancak bu sözcük Nick'in kontrolünden çıkar, önce okula ve kasabaya sonra tüm dünyaya yayılır. Olanlara Nick de çok şaşkındır. Dilin yaşayan ve gelişen özelliği üzerine muzip bir öyküdür.

\section{3. İletiye ilişkin bulgular}

Araştırmada incelenen kitapta geçen öykü, sözcüklerin doğuşuna farklı bir bakış açısı kazandıran, dilin canlılığı, gelişimi, zenginleşmesi, dil kurallarının sorgulanması üzerine iletiler barındırmaktadır. 
An investigation of Andrew Clements novel in the name of Frindle in terms of suitability for children / B. Varışoğlu, Ş. H. Tuzcuoğlu Aksin (p. 639-656)

Parmağını kaldırdı ve Bayan Granger'in söz vermesini bile beklemedi. "Evet ama, yani, ben hâlâ sözcüklerin niye farklı farklı anlamlar taşıdığını anlayamadım. Örneğin k-ö-p-e-k'in, havlayan ve kuyruğunu sallayan şeydemek olduğuna kim karar veriyor? Bunu kim diyor?" (s. 39)

Diğer yandan parlak bir zekânın önünün her zaman açık olduğu, bunu ortaya koyarken bir cesaretin gerektiği de vurgulanan diğer iletidir.

Düşüncelerin hayata geçirilmesi için saygı ve dürüstlükten ödün verilmemesi, yaşamda maddiyattan ziyade yaşam becerileri ve kendi ayakları üzerinde durmanın daha önemli olduğu kitaptan alınan mesajlar arasindadır.

Annesi divanda oturduğu yere geri döndü ve "Nick, bu konu üzerinde biraz daha konuşsak iyi olacak" dedi. "Okulda Bayan Granger ya da herhangi bir öğretmene karşı saygısızlık ettiğini görürsem başın belada demektir." (s. 63-64)

Tom çeke bakıp başını salladı. "Bu müthiş bir şey, Bud. Gerçekten çok sevindim çünkü Nick'in üniversite eğitimine ciddi katkısı olacak. Ama ikimizin arasında kalmasını rica ediyorum. Nick bunu duyacak olursa, bir daha ne çimleri biçer ne de tek kuruş biriktirir herhalde. Yani, aramızda kalsın işte, tamam mi?” (s. 91)

Okul ortamında özgür düşünen bireylerin yetiştirilmesi için değişmez sanılan kuralların da sorgulanabilir olduğu kitapta verilmek istenen ana düşüncelerden biridir. Kuralları sorgulayan çocuğun eleştirel düşünme yetisi hakkında İpşiroğlu (2009, s. 301) "önemli olanın bağımsız düşünme yetisini yitirmeden bir sorunu çeşitli açılardan inceleyerek kendi görüşünü geliştirme, aynı zamanda başkalarının görüşlerine de saygı ve hoşgörüyle yaklaşmak" olduğunu belirtmiştir. Sever'e göre (2018, s. 110) "eleştirel okur okuduklarını, izlediklerini, dinlediklerini sınama, sorgulama yeterliliği kazanmış; düşünme yetisi edinmiş, demokratik kültürü içselleştirmiş, duyarlı bireydir.". Bu anlamda, incelenen kitapta yer alan iletiler çocuk okura eleştirel okuma becerisi kazandırma açısından önem taşımaktadır.

\section{Karakterlere ilişkin bulgular}

Çocuk edebiyatındaki karakterler kapalı (geliştirilmemiş) ve açık (geliştirilmiş) olarak adlandırılarak iki grupta incelenebilir. Kapalı karakter, özellikleri yüzeysel olarak tanıtılan, okurun iyi tanımadığı karakterdir. Bu karakterlerin çocuklara insan doğasını kavratma, yaşam gerçekliğini anlatmada çok az katkıları vardır.

Açık karakter roman, öykü, masal ve anlatılarda birçok özelliğiyle okura tanıtılan, inandırıcı nitelikleriyle öne çıkan, okurun iyi bildiği karakterdir. Bu karakter, yazarın aktarmak istediği iletilerin okurlarla paylaşılmasında etkin bir sorumluluk üstlenir (Sever, 2012, s. 104). Andrew Clements'in Bunun Adı Findel adlı öykü kitabında baş kahraman 5. sını öğrencisi Nick Allen'dır. Nick okuyucuya birçok özelliğinin tanıtılması bakımından açık karakter özelliği göstermektedir. Kitapta Nick'in açık karakter oluşuna ilişkin şu örnek ifadeler gösterilebilir:

"Lincoln İlkokulundaki çocuklarla öğretmenlerden -harbiden kötü, harbiden akıllı ve harbiden iyi çocukları içeren- üç liste yapmalarını isteseniz, Nick Allen bunların hiçbirinde yer almazdı. Nick tamamen kendine özgüydü ve herkes de bunu bilirdi. Peki Nick bir baş belası mıydı? Öyle de denemez. Kesin olan şuydu: Nick Allen'ın her zaman bir dolu fikri vardı ve onları kullanmayı iyi bilirdi." (s. 11)

"Lincoln İlkokulu'nun arada bir sarsılıp kendine gelmesi gerekiyordu ve Nick de tam bunu sağlayacak kişiydi." (s. 13)

"Nick ders kaynatma sorularında uzmandı. Bu yüzden ders kaynatıcı ya da garantili zaman geçirici olarak da tanınırdı." (s. 24) 
"Eylem"se Nick'in göbek adıydı. (s. 46)

Kitapta açlk karakter özelliği gösteren bir diğer kişi Nick'in dil bilgisi ve edebiyat öğretmeni Bayan Granger'dir. Kitapta onun açık karakter oluşuna ilişkin şu örnek ifadeler gösterilebilir:

"Her sabah, ister güneş ister yağmur, ister kar ister buz, ister ayaz ister firtına olsun soluk mavi eski otomobiliyle okula gelirdi. Onca yıl devamsızlık ettiğini anımsayan yoktu." (s.16)

"Herkes Bayan Granger'in x-ışınlarıyla gördüğünden emindi. Onun 15 metre yakınında sakız çiğnemeyi aklınızdan biler geçiremezdiniz." (s.17)

"Bayan Granger terlemek nedir bilmeyen insanlardandı. Ceketini çıkarması için sıcaklığın otuz derecenin üstüne çıkması gerekirdi." (s.17)

"Sözlüğe bayılmak ne kelime, sözlüğe âşıktı-neredeyse ona tapıyordu." (s.18)

Bayan Granger'in amacı yeni ve saçma, köksüz bir sözcük üretilmesine karşı çıkmaktan ziyade yeni fikirler, sorgulanabilir görüşler ve sözcüklerin köküne dair maceraperest bir hevesin kıvılcımını çakmaktır. Böyle yaparak Nick'in parlak zekâsını desteklemiştir. Olağanüstü bir sabır ve tecrübe ile Nick'teki parlak zekâyı keşfeden ve bu zekâyı körükleyen şekilde davranmıştır.

Bayan Granger'in findel sözcüğünü kullananlara uyguladığı ceza, Nick'in kendi sözcüğüne ne kadar inandığını ve çevresini ne kadar ikna edebileceğini göstermek içindir. Bunun için kötü karakter olmayı tercih etmiştir. Nick'in kendi macerasını doğurabilmesi için kötü ve kışkırtıcı olmayı göze alır. Keskin bakışlarının altında ışıldayan gözlerinde kalem yerine findel demeyi yasaklayan kötü öğretmenin zekice hazırlanmış planının hazzı vardır.

Nick, kuralları sorgulayan, okuma ve sözcüklerle arası iyi olan bir çocuktur. Nick'in daima parlak fikirleri vardır. Ve bu fikirleri yaşama geçirmekte cesurdur.

"Eylemse Nick'in göbek adıydr." Bu karakter özelliği çocuğa girişimci olmayı, karar alabilmeyi ve bu kararları uygulayıp arkasında durabilmeyi temsil etmektedir.

Yaşam düzenine ilişkin fikirleri olan bir kahraman içinde bulunduğu ev, aile ve okul sistemini sorgular. Arkadaşlarıyla vakit geçirmekten hoşlanan Nick'in karakter yapısının oluşmasında rolü olan etkenlerden biri hiç şüphesiz ailesidir. İlkeli, kuralları olan, çocuk eğitiminde disipline yer veren, çocuğuna güvenen ve ona sorumluluklar veren, çocuğunun hatası karşısında soğukkanlı ve çözümcü olabilen, gerektiğinde özür dileyen bir aileye olduğu görülür. Nick'in okuma ve sözcüklerle olan kuvvetli bağı yine okuma kültürüne sahip ailenin evinde bulunan kitaplığından anlaşılır. Bu kitaplık yalnızca yetişkinler için değil, çocuk okura yani Nick'e seslenen bir bölüm de barındırmaktadır: "Nick'lerin evinde bir kural vardı: Önce Ev Ödevi”. (s. 27). "Nick'in ailesi çok kitap okurdu. Dolayısiyla oturma odasının dört duvarından üçü kitap raflarıyla kaplydı. İki ayrı ansiklopedi serisi vardı. Siyah seri büyükler krrmızı seri çocuklar içindi." (s. 30).

Düşünen, sorgulayan, duyarlı bir birey olma yolunda olan çocuk kahramanımız Nick'in karakterinin oluşmasında yine çocuklarının hatalarını savunmayan, kontrolü elden bırakmayan ama bu kontrol ve düzende çocuğa özgürlük alanı tanıyan, çocukları dinleyerek onları bir birey olarak gören, onların görüşlerine önem veren ve kararlarına saygı duyan, öğretmen ve büyüklere karşı saygı duyulmasını öğütleyen, onun birey olma serüvenine katkıda bulunan anne babasının rolü görülmektedir. Bu da aslında okumanın öncelikle ailede başladığını, bunu bir ayrıcalık değil yaşam kültürü ve becerisi haline getirmenin ne denli önemli olduğunu göstermektedir: "Nick bu konu üzerinde biraz daha konuşsak iyi 
olacak. Okulda Bayan Granger ya da herhangi bir öğretmenine karşı saygısızlı ettiğini öğrenirsem başın belada demektir." (s. 64).

Nick'in kavuştuğu ünden rahatsızlık duyan mütevazı bir yaşam süren ailesi, maddiyata önem vermeyip çalışmanın, saygı, başarı ve dürüstlüğün temel değerler olduğu yaşamlarında, findel satışlarından elde edilen paraya güvenmemesi için Nick'i haberdar etmemişlerdir:

"Gerçekten çok sevindim. Çünkü Nick'in üniversite eğitimine ciddi katkısı olacak. Ama ikimizin arasında kalmasını rica ediyorum. Nick bunu duyacak olursa bir daha ne çimleri biçer ne de tek kuruş biriktirir herhalde. Yani, aramızda kalsın iște, tamam mı?" (s. 91). "Nick paranın bir kısmını anne ve babasına vermek istediyse de, Allen'lar ihtiyaçlarının olmadığını söyleyerek kabul etmediler." (s. 102).

Kitapta olay örgüsünde yer alan yan kahramanlar ise şunlardır:

Bud Lawrence: İş adamı

Manny: Okul hizmetlisi

Bayan Deaver: Öğretmen

Bayan Avery: Öğretmen

Janet Fisk: Nick'in sinıf arkadaşı

Bayan Lorelei Granger: Dil bilgisi ve edebiyat öğretmeni

Bayan Allen: Nick'in annesi

Tom Allen: Nick'in babası

James Allen: Nick'in ağabeyi

John: Nick'in sınıf arkadaşı

Pete: Margaret Chatham: Lincoln İlkokulu Müdürü

Chris: Nick'in sınıf arkadaşı

Dave: Nick'in sınıf arkadaşı

Alice Lunderson: Muhabir

Juddy Morgan: Westfield gazetesi muhabiri

Ted Bell: Westfield gazetesi reklam bölümü çalışanı

Bayan Freed: Okul sekreteri 


\section{Dil ve anlatıma ilişkin bulgular}

Araştırmada dil ve anlatım ile ilgili isim ve sıfat tamlamaları, zıt anlamlı sözcükler, karşılaştırma cümleleri, devrik cümleler, betimlemeler, benzetmeler, deyimler, ikilemeler, yansıma sözcükler, ara söz ve cümleler, iç konuşmalar incelenmiştir. Dil ve anlatım özelliğinin kitabın çevirisiyle ilgili olduğunu, bu hususun kitabın orijinali hakkında bilgi vermediğini belirtmek gerekir. Söz gelimi "Oğulları Nicholas, hiç lamı cimi yok, yaman bir çocuktu doğrusu." (s. 79) cümlesinde geçen "lamı cimi yok" deyimi Arap alfabesinde bulunan "lam" ve "cim" harflerinden oluşan bir deyimdir. Bu deyimin ele alınan kitabın yazarı Andrew Clements'in bağlı bulunduğu Amerikan kültürü ve söz varlığında yer almadığı açıktır. "Dile ait ögelerden bazıları kültürel bağlamda değerlendirilememektedir. Örneğin deyimlerin değerlendirilmesi bu açıdan bakıldığında tamamen çevirmenin bu alandaki başarısına bağlıdır." (Mert, Albayrak ve Serin, 2013, s. 64). Bu çerçevede kitabın çevirmeni Mine Kazmaoğlu dili zengin ve güçlü bir biçimde kullanarak kültürlerarası iletişim sağlamaya çalışmıştır.

\section{İsim tamlaması}

Kitapta geçen isim tamlamalarına örnekler:

güneş gözlüğü, okulun ilk günü, ders kuralları, el yazısı, ödev başlıkları, ders kaynatma soruları, ev ödevi, sözcük dedektifleri, yazılanların çoğu, duyduklarının yarısı, kapının dışı, şakanın dozu, dil bilgisi öğretmeni, dağ bisikleti, babasının bilgisayar donanımı dükkânı, kasa kuyruğu, Nick'in üniversite eğitimi, Findel'in resmi üreticisi, Bayan Granger'in evinin kapısı, ticari kullanım hakkı, çocukların findel talebi, Cadılar Bayramı, Lincoln ilkokulunun hikâyesi, onun gerçekleri ifade ediş biçimi, Eğitim kuralarının sorgulanmasını, gazetenin reklam servisi, okul yönetim kurulu üyesi, şakanın dozu, bakış açısı farklılı̆̆ı, anne ve babasının yüz ifadeleri, konferans salonunun sahnesi, şeref meselesi, okul otobüslerinin şoförleri, hamburgerinin geri kalanının tadı, okula ısınma günü, ders kaynatma soruları, oturma şeması, sözcük dedektifi.

\section{Sifat tamlaması}

Kitapta geçen sıfat tamlamalarına örnekler:

küçük, işlemeli akik broş; koyu gri gözler; parlak, sarı, küçük bir karton; tam takım otuz sözlük; gerçek olamayacak bir tatlllık, sallanan koltuk, öteki akıllı insanlar, derin bir soluk, küçük bir sözlï rapor, üç dakikayı dolduracak malzeme, küçük sakin bir kasaba, yüz adet cümle, şifre sözcük, özgür basın, kargacık burgacık el yazısı, elini dolduran, zarif,, ağır bir kalem; yeni, güçlü bir bilgisayar; cömert bir pay; açık ve adil bir sözleşme; yaman bir oğlan; kasabada satılan, üstünde findel yazılı şu parlak kırmızı tükenmez kalemler; suya sabuna dokunmayan tatlı bir konușma; düzen ve otoriteyi temsil eden güçlerin savunucusu Bayan Granger, doğu bulvarı boyunca dikilecek on sekiz yeni ağaç, okulda alıkonulan çocuklardan biri yüzünden şikayetçi olan bir veli, kapının dışında asılı duyuru, sırt çantasının ağırlığından devrilecek gibi duran bir oğlan, kızıl kahverengi saçlı gözlüklü bir oğlan, divanın solundaki iskemle, müdürün tam karşısındaki sallanan koltuk, birinci sınıf bir fikir bombası, aşırı bir tepki, huzursuz bir sessizlik, yeni bir sözcügün ortaya atılabileceği en uygun yer, yedek bir findel, mavi kapaklı kestane rengi eski dolma kalem, küçük masanın üstünde duran kocaman sözlük, berrak düşünce yetisi, işini bu kadar ciddiye alan bir öğretmen; kafa yorucu, bomba gibi bir soru; gıpgıcır kırmızı sözlük, dar beton bordür, hoş name, ağaçların kocaman, evlerin küçücük olduğu mahalleler.

\section{Zit anlamlılar}

Kitapta geçen zıt anlamlılara örnekler:

"Ve sokaktan assağıya, merdivenlerden yukarıya, kapıdan içeriye ve yukarı kattaki odasına koşuncaya kadar da yalnızca parlak bir fikir olmaktan çıkmıştı artık." (s. 46)

"Bayan Granger'in gözlerinde bir kıvılcımyanıp söndü." (s. 55) 
An investigation of Andrew Clements novel in the name of Frindle in terms of suitability for children / B. Varışoğlu, Ş. H. Tuzcuoğlu Aksin (p. 639-656)

"Biri kazanıp diğeri kaybedene kadar sürecekti." (s. 63)

"Bütün iyi öykülere kötü bir karakter gerekir, öyle değil mi?” (s. 106)

\section{Karșılaștırma cümlesi}

Kitapta geçen karşılaştırma cümlelerine örnekler:

“Bütün öğretmenler gibi o da kısa boyluydu.” (s. 17)

"Onunkinden önce başka sözlükler de varmış gerçi ama Johnson'ın sözlüğünün en önemli farkı kapsamıymış." (s. 34)

"Ama benim için findel de bir o kadar anlamlı dedi Nick." (s. 55)

"Bakışları Nick'in daha önce hiç görmediği kadar parlaktı." (s. 100)

\section{Devrik cümleler}

Kitapta geçen devrik cümle örnekleri:

"Üçüncü sınıftayken bir keresinde Bayan Deaver'in sınıfını tropik bir adaya dönüştürmeye karar vermişti Nick.” (s. 11)

"Bayan Granger henüz okul başlamadan Nick ve arkadaşları daha beşinci sınıf öncesi yaz tatilindeyken işe koyulmuştu bile.” (s. 20)

"Savaşlarda yapılan müzakerelere benziyordu bu." (s. 53)

\section{Betimleme}

Kitaptaki betimlemelere örnekler:

"Gözleri alev alevdi ancak kor gibi yanmıyor da daha çok ışık saçıyor gibiydiler." (s. 49)

"Babası kadar uzun boylu, geniş̧ omuzlu, iriyarı biriydi müdür hanım. Bir futbol takımında olsa savunma hattında oynardı bu kadın, diye düşündü Nick.” (s. 60)

"Gri, belki yer yer altın sarısı benekli ve çok keskin ama sert ya da zalim değil, yalnızca parlak ve güçlï.” (s. 70)

\section{Benzetmeler}

Öyküde benzetmeler günlük hayatla iç içe ancak şaşırtıcı ve mizahi bir anlatımla sunulmuştur:

"Ertesi gün sessiz okuma yaparlarken Nick öğretmene bir göz attığında Bayan Avery'nin atmaca gagası gibi kanca burunlu olduğunu fark edince "Ciik!" diye tiz, cırlak bir kara tavuk sesi çıardı." (s. 13)

"İyice beyazlaşmış saçlarını başının arkasında, kuş yuvasına benzer bir topuz yapıyordu." (s. 17)

"Koyu gri gözlerini bütün dikkatiyle üstünüze çevirdiğinde kendinizi bir toz zerresi gibi hissedebilirdiniz." (s. 17)

\section{Deyimler}

Öykü, deyimlerin kullanımı açısından oldukça zengindir. Bir dilin anlatım zenginliğini ortaya koyan deyimlerin fazlaca yer alması çocukların dilin inceliklerini, farklı kullanımlarını görmelerini artırmıştır.

"Ama üstlerine basıldıkça kumlar koridora yayılmaya başlayınca bunu hiç de yaratıcı bulmayan okul hademesi Manny burnundan soluyarak doğruca müdüriyete gitti.” (s. 12) 
"Henüz altı aylık, çiçeği burnunda bir öğretmen olan Bayan Deaver bayıldı buna.” (s. 12)

"Onun on beş metre yakınında sakız çiğnemeyi aklınızdan bile geçiremezdiniz." (s. 17)

"Keskin, gri gözleri henüz dikkat kesilmemişti." (s. 24)

"Çocukların kimi sırıtırken kimi saate göz attı." (s. 25)

"Bayan Granger'in dersinde bütün sınıfin önüne çıkacak ve herkesin gözü onun üstünde olacaktı." (s. 32)

"Ama okuldan sonra berbere ya da üst baş alışverişine gitmek zorunda olduğumuzda gün zzzzızt diye göz açıp kapanıncaya kadar geçiverirdi." (s. 33)

"Ve Bayan Granger zokayı yuttu." (s. 39)

"Nick bir daha Bayan G'nin yoluna taş koymaya kalkışmadı." (s. 41)

"Onu biraz yavaşlatabilmişti ama önünü kesebilmiş miydi?" (s. 41)

"Derken Bayan Granger'in dersin sonunda sözcükler hakkında söyledikleri kafasına dank etti." (s. 43)

"Oturdukları sokağın köşesine geldiklerinde aklı başka yerde olan Nick ona çarpmıştı." (s. 44)

"Sağ ellerini havaya kaldırarak Nick'in kaleme aldığı yemini okudular." (s. 47)

"Nick bilerek tutamadı ve bir şamata kopararak yerlerde arandı." (s. 49)

"Ancak bu, okuldaki bütün çocukların yeni sözcüğü dillerine dolamalarına neden oldu." (s. 52)

"Ancak bu herkesin Nick'in yeni sözcüğünü daha da çok kullanmak istemesinden başka işe yaramadi." (s. 52)

"Bayan Granger bu savaştan zevk alıyor, kazanmak için yanıp tutuşuyor!" (s. 56)

"Yüzü asıktı ama gözleri ... Gözleri farklı telden çalıyor, neredeyse mutluluk saçıyordu." (s. 56)

"Yoksa canımıza okur Kül Yutmaz bizim." (s. 57)

"Okulda canımızı sıkan bazı şeyle oluyor ve anlaşılan Nick de başı çekiyor dedi müdür hanım." (s. 6o)

"Okulda canımızı sıkan bazı şeyler oluyor ve anlaşılan Nick de başı çekiyor, dedi müdür hanım." (s. 60)

"Nick gıkını çıkarmadan oturmaya devam etti." (s. 61)

"Müdür hanım iç çekerek şöyle yanıtladı." (s. 61)

"İşte bu noktada Nick burnunu soktu." (s. 61)

"Ama saçma sapan bir şey yüzünden çok fazla tantana koparılmış gibi gelmiyor mu size?" (s. 61)

"Üçü de apışıp kalmıştı." (s. 62)

"O sözcüğe ilişkin her şeyden gına gelmişti artık." (s. 68)

"Judy aklına koymuşsa er geç dil bilgisi öğretmeniyle konuşurdu." (s. 69)

"Judy onun arkasından odadaki bütün çocukların kulak kesildiklerini görebiliyordu." (s. 70)

"Zamanlarını boşa harcıyor, boşuna kafa yoruyorlar!" (s. 70)

"Judy onların gülüşüp şakalaşmalarına kulak vererek yanları sıra yürüyordu." (s. 71)

"Oğulları Nicholas, hiç lamı cimi yok, yaman bir çocuktu doğrusu." (s. 79)

"Ama laf aramızda, Bud, hepsi unutulup gitse diye dört gözle bekliyorum." (s. 88)

"Zamanlarını boşa harcıyor, boşuna kafa yoruyorlar!" (s. 70)

"Birisi tarafından tanındığını hissedince utanıyor, eli ayağına dolaşıyordu." (s. 78)

"Nick'in anne ve babası her ne kadar oğullarının bütün kasabanın diline dolanmasından rahatsızlık duysalar da, gizli gizli bundan hoşnuttular da." (s. 79)

"Çoğu perşembe günleri çıkan bu gazetelerin onun eline ulaşması pazartesi ya da salıyı bulur; Alice'in hepsini gözden geçirmesi de bir iki gününü alırdı." (s. 81)

"Onun için ağzından çıkanı kulağın duysun." (s. 83) 
"Nick ve ailesinin ağzından tartışma yaratacak bir şeyler çıkmayacağını anlamış, suya sabuna dokunmayan tatlı bir konuşma sürdürmeye çalışıyordu." (s. 84)

"Alt tarafı bir sözcük için bu kadar gürültü koparmak abartılı gözüküyor biliyorum." (s. 90)

"Tom Allen'ın aklı yattı." (s. 91)

"Bütün hevesi kaçtı." (s. 97)

"Kalem sözcüğünün hiçbir önemi yokmuşçasına bir kenara itilmesine gönlüm razı gelmemişti." (s. 105)

\section{İkileme}

İkilemeler, kullanılan dilin zenginliğinin başlıca göstergelerinden biridir. Anlamı pekiştirme, kolaylaştırma, güzelleştirme ve abartma gibi görevleri üstlenirken aynı zamanda anlatıma estetik katan unsurlardır. Ahenkli bir söyleyişe sahip olmaları da ikilemeleri ilgi çekici kılan bir özelliktir. Çocukların ana dili farkındalıklarını geliştirirken ve onların söz varlı̆̆ını zenginleştirirken ikilemelerin bu özelliklerinden faydalanmak gerekir (Yıldırım Bilgen, 2017, s. 147).
"Bayan Granger kentin daha eski bir mahallesinde derli toplu küçük bir evde tek başına oturuyordu." (s. 16)
"Bir günlüğüne kaytarıp o sözcüğü defterinize yazmayacak, sözlükten bakıp anlamını öğrenmeyecek olsanız Bayan Granger önünde sonunda bunun farkına varır.” (s. 20)
"Kalbi gümbür gümbür atıyor, kendini yerin dibine batmış hissediyor.” (s. 26)

\section{Yansima}

Kitapta yansıma ifadelerden de yararlanılmıştır:

"Bu büyük rakam karşısında sınıftakiler "Off!", "Vay canına!" gibi nidalarla patırtı kopartınca Nick'in dikkati dağıldı.” (s. 34)

"Derken -pat- yeni bir fikir geldi Nick'in aklına." (s. 96)

"Okulun son günü Bayan Granger'in sinıfinın kapısını tıklattı." (s. 99)

"Bayan Granger öfkeyle yazım hatalarına baktı ama sonra başını sallayarak kıkırdadı." (s. 111)

\section{Ara söz ve cümle}

Anlatımda sık sık ara söz ve cümleler yer almıştır. Ara sözler anlatılanları okurun zihninde daha iyi canlandırmak ve anlatımı zenginleştirmektedir. Bu kullanım aynı zamanda öykü anlatıcısının araya girerek düşüncesini bildirmesine de olanak sağlamıştır.

“Ama Bayan Granger sözlüğe bayılmak ne kelime, sözlüğe âşıktı -neredeyse ona tapıyordu.” (s. 18)

"Nick çantasına uzanıp evden getirdiği çocukların çoğunun sahip olduğu -hani bayan Granger'in kullanmaları gerektiğini söylediği- kırmızı sözlüğü çıkardı.” (s. 36)

“Eğilip altın yaldızlı bir tükenmez kalem aldı yerden -hani şu gösterişli olanlardan.” (s. 42)

\section{İç konuşmalar}

Öyküde, başkahraman Nick'in, yaşadıkları karşısında düşündükleri ve olaylara tepkileri iç ses olarak ara ara iç konuşmalar ile okura aktarılmak istenmiştir.

"Bu öğretmen hakkında duyduklarının hepsi doğruydu -Kül Yutmaz diye anılan bir öğretmenle uğraşmaya kalkışmayacaksın.” (s. 26) 
“Bu kadın sağlam oynuyor diye düşündü Nick.” (s. 33)

\section{Eğitsel ilkelere ilişkin bulgular}

Okuma kültürü ele alınan değerlerden biridir. Okumayı seven ve okumanın öneminin farkında olan bir çocuk yetiştirilmesinde rol oynayan en büyük etkenin ailedeki yerleşik okuma kültürü olduğu Nick'in ailesinin evindeki kütüphaneden anlaşlmaktadır.

"Nick'in ailesi çok kitap okurdu. Dolayısıyla oturma odasının dört duvarından üçü kitap raflarıyla kaplıydı. İki ayrı ansiklopedi serisi vardı. Siyah seri büyükler kırmızı seri çocuklar içindi.” (s. 30).

Düşüncelerin hayata geçirilmesi için saygı ve dürüstlükten ödün verilmemesi, yaşamda maddiyattan ziyade yaşam becerileri ve kendi ayakları üzerinde durmanın daha önemli olduğu görülmektedir. Bu durum çocuk okura, çalışmanın, emek vermenin en değerli kazanç olduğunu vurgulamak açısından önemlidir.

"Gerçekten çok sevindim. Çünkü Nick'in üniversite eğitimine ciddi katkısı olacak. Ama ikimizin arasında kalmasını rica ediyorum. Nick bunu duyacak olursa bir daha ne çimleri biçer ne de tek kuruş biriktirir herhalde. Yani, aramızda kalsın işte, tamam mı?" (s. 91)

Nick'in annesinin öğretmen ve büyüklere karşı saygı duyulmasını öğütlemesi değerler eğitimi açısından dikkate değerdir.

"Okulda Bayan Granger ya da herhangi bir öğretmenine karşı saygısızlk ettiğini öğrenirsem başın belada demektir." (s. 64)

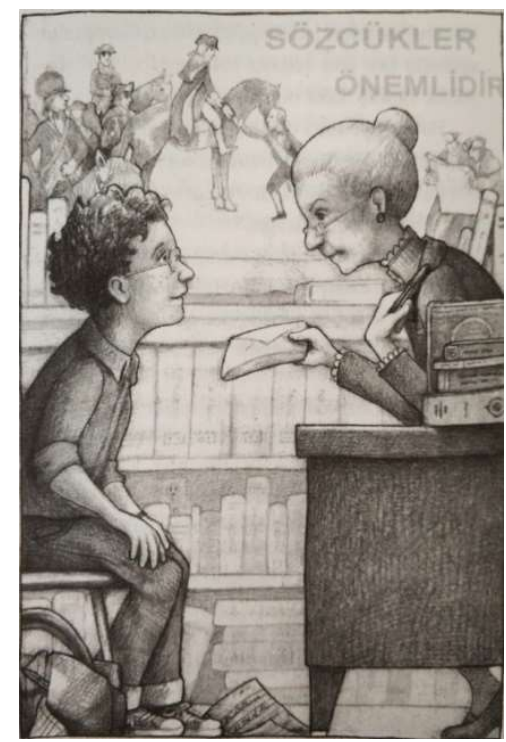

Resim 3. Bunun Adı Findel adlı eserin bir sayfası (s. 54)

\section{Sonuç ve tartışma}

Demokratik ve çağdaş toplum olmanın en önemli değişkenlerinden biri bireylerin okuma kültürü edinmesidir. Okuma kültürü, erken çocukluktan başlayarak duyarlı ve bilinçli çabalarla edinilmesi gereken yaşamsal bir süreçtir. Bu bağlamda okuma kültürü edinme, bireyin; estetik duyarlılıkla 
oluşturulmuş yazılı ve görsel kültür ürünleriyle buluşması, başka bir söyleyişle okuma eylemini yaşam biçimi olarak içselleştirmesiyle ilişkili bir süreçtir (İnce Samur, 2017, s. 212). Okuma kültürü edinme sürecinde çocuk okur, pek çok kitapla karşılaşmaktadır.

Geleceği oluşturacak çocukların nitelikli eserlerle tanışması önemlidir. Ebeveyn ve öğretmenler bu amaçla, çocukları sadece klasik çocuk kitaplarıyla değil günümüzde yayımlanan nitelikli çocuk kitaplarıyla da tanıştırmalıdır (Tekin, 2017, s. 2).

Nitelikli çocuk yayınları, çocuğun kendini ve çevresini algılayıp anlamlandırması, bağımsız düşünme yeteneği edinmesi, temel dil becerilerini geliştirmesi yolunda önemli bir misyonu yerine getirirler. Böylelikle çocukların insani, toplumsal, çağdaş değerleri içselleştirmesini, bu değerleri yaşamında aksiyona dönüştürmesini, toplumun huzur ve refah seviyesinin artması gibi pozitif kazanımlara daha kolay erişmesini sağlar (Karagöz, 2015).

Çocuklara seslenen yapıtlar; çocuğun coşkusuna, düşüncelerine ve gülmece anlayışına dil ve çizginin anlatım gücüyle ulaşabildiği oranda işlevini yerine getirebilir. Çocuğa yeni yaşantılar kazandıran bu yapıtlar çocuğun kitabın sunduğu anlam evrenine daha kolay girmesine, kahramanlarıyla daha çabuk etkileşim kurmasına katkı sağlar. Unutulmamalıdır ki çocuk edebiyatının öncelikli amacı, öğüt vermek ya da öğretmek değildir. Çocuklara yaşam ve insan gerçeğine ilişkin sanatçı duyarlılığı ile kurgulanmış ipuçları sunmak, ana dilinin kullanım olanaklarını sezdirmek ve onları yazılı kültürle sağlıklı etkileşim kurabilen bireyler kılabilmek çocuk edebiyatının temel amacı olmalıdır. Bu nedenle çocuk ve edebiyat ilişkisi açısından kitapların bazı temel ilkelere dayandırılması gerekir.

Kitaplar, dilsel ve görsel özellikleriyle çocuğun hem sanat hem de düşünme eğitimi sürecini desteklemelidir. Çocuğun kendini özgürce gerçekleştirebilmesine (düşünmesine, düşlemesine, gülmesine, eğlenmesine vb.) olanak sağlayacak yaşam durumları, dilin anlatım ustalığıyla kurgulanarak çocuklara sunulmalıdır. Kitaplar çocukları okumaya isteklendirecek bir tasarım anlayışını yansıtmalı; çocuklar kendileri için üretilen bir araca verilen önemi, gösterilen saygıyı, kitabın dış yapı (biçimsel) özellikleriyle bütünleşmiş olan tasarım özeninden anlayabilmelidir. Kitaplardaki resimler, metnin iletisine görsel bir zenginlik katmalı, kahramanların kişilik özelliklerine uygun biçimde çizilmeli, estetik nitelikleriyle görsel algılarını geliştirici özellikler taşımalıdır (Sever, 2012).

Tüm bu çerçevede Andrew Clements’in Bunun Adı Findel adlı çocuk kitabı incelendiğinde şu sonuçlara ulaşılmıştır:

Yapıt, çocuğun taşıyabileceği büyüklüktedir. Yapıtta kullanılan kâğıdın çocuğun gözünü yormayacak özellikte, dayanıklı ve orta kalitede olduğu belirlenmiştir. Tüm yapıtların kapak kâğıdı görsel tasarımın etkisini koruyacak ve sürdürebilecek özelliktedir. Kapak ve iç kapak tasarımlarındaki görsel ve dilsel ögeler çocuğa göredir.

İncelenen yapıttaki resimlerin çocukların konu hakkında betimleme yapmalarına yardımcı olur nitelikte, temel düzeyde ve siyah-beyaz olarak yer aldığı sonucuna ulaşılmıştır.

Kitap konu açısından dilin gelişimi ve canlılı̆̆ı, özgür düşünme, hayal gücü ve yaratıcllık üzerine kurgulanmıştır. Kitapta yer alan olayların çocukların gülmesine, heyecanlanmasına, düş kurmasına ve düşünmesine olanak sağladığı belirlenmiştir. Bunun yanında okuma kültürü gelişmiş bir aile profili, ailenin çocuğu bir birey olarak değerlendirip ona güvenmesi, otorite ve kuralları sorgulama, olaylar 
karşısında dürüstlük ve saygı değerlerinin gözetilmesi konularında çocuğa duyarlılık kazandırabileceği tespit edilmiştir.

Kitapta sık sık kurallar sorgulandığı için eleştirel düşünme ve geniş hayal gücünün ortaya çıardığı yaratıcılık temalarının işlendiği görülmüştür. Bu temalardaki iletiler çocuğa kurgunun içinde mizahi bir anlatımla sunulmuştur. Böylece çocuk edebiyatının temel ilkelerinden mizah kullanılarak çocuğun kitabın anlam evrenine erişmesi sağlanmaktadır.

Karakter çerçevesi açısından kitapta yer alan kahramanların çocuğun sevgi ve güven ihtiyacına yanıt verebilecek özellikte olduğu sonucuna ulaşılmıştır. Kitaptaki kahramanların ilkeli, anlayışlı, güvenilir olma özellikleri öne çıkmaktadır.

Dil ve anlatım açısından kitapta karakter ve olay betimlemeleri güçlü sıfatlarla, dilin geniş anlatım zenginlikleri kullanılarak yapılmıştır. Anlatımda deyimlere, sıfat ve isim tamlamalarına, ikilemelere çokça yer verildiği tespit edilmiştir. Bu kullanımın okuyucunun anadilinin olanaklarını tanımasına, anlam zenginliğinin farkına varmasına ve anadilini etkili şekilde konuşmasına yardımcı olacağı düşünülmektedir.

Eğitsel ilkeler açısından kitabın okuyucunun okuma, yazma ve konuşma becerilerinin gelişmesine, okuma alışkanlığı edinmesine yardımcı olacağı sonucuna varılmıştır.

Genel olarak bakıldığında Bunun Adı Findel adlı kitabın gerek özgün konusu gerekse anlatım gücüyle çocuk okurun çok seveceği, çocuk edebiyatının baş yapıtlarından biri olduğu söylenebilir.

\section{Kaynakça}

Arıkan, Y. (2018). Behiç Ak'ın çocuk kitaplarının çocuk edebiyatının temel öğeleri bakımından incelenmesi. (Yayımlanmamış yüksek lisans tezi). Zonguldak Bülent Ecevit Üniversitesi, Zonguldak.

Aslan, C. (2013). Çocuk edebiyatı yapıtlarının temel işlevleri. Eğitimci Öğretmen Dergisi, 17, 6-9.

Büyüköztürk, S.., Kılıç Kaynak, E., Akgün, Ö. E., Karadeniz, Ş. ve Demirel, F. (2013). Bilimsel araştırma yöntemleri. Ankara: Pegem Akademi.

İnce Samur, A. Ö. (2014). Türkiye'deki ve dünya'daki çalışmaların tanıklığında "Okuma Kültürü". Hasan Ali Yücel Eğitim Fakültesi Dergisi, 11(22), 157-188.

İnce Samur, A. Ö. (2016). Okuma kültürü nasıl kazandırılır Okulöncesi Dönem / o-6 yaş. Ankara: Anı Yayıncilı.

İnce Samur, A. Ö. (2017). Okuma kültürü edinme sürecinde “ílkokul Dönemi (6-10 yaş)”. Ankara Üniversitesi Eğitim Bilimleri Fakültesi Dergisi, 5o(1), 209-230.

İpşiroğlu, Z. (2009). Düş hırsızlarına karşı. İstanbul: E Yayınları.

Karaca, G. ve Temizyürek, F. (2017). Sevim Ak’ın öykülerinin çocuğa görelik ilkesi açısından incelenmesi. Bartın Üniversitesi Eğitim Fakültesi Dergisi, 6(1), 177-195.

Karagöz, B. (2015). Yalvaç Ural'nn eserlerinin tematik açıdan incelenmesi ve eserlerinde çocuk eğitimiyle ilgili temel değerler. (Yayımlanmamış doktora tezi). Atatürk Üniversitesi, Erzurum.

Karasar, N. (2009). Bilimsel araştırma yöntemi. Ankara: Nobel Yayınları.

Kavcar, C. (1999). Edebiyat ve eğitim. Ankara: Engin Yayınevi.

Kirazlı, N. (2018). Behiç Ak’nn çocuk edebiyatı yapıtlarının çocuğa görelik açısından incelenmesi. (Yayımlanmamış yüksek lisans tezi). Ankara Üniversitesi, Ankara. 
Mazlum, Ö. ve Mazlum, F. S. (2016). İlköğretim 4. sınıf ders kitaplarının görsel tasarımına yönelik öğretmen görüşlerinin değerlendirilmesi. Sanat Ĕ̆itimi Dergisi, 4(1), 1-18.

Mert, O., Albayrak, F. ve Serin, N. (2013). Çeviri çocuk kitaplarının kültür aktarımı açısından incelenmesi. Ana Dili Ĕ̆itimi Dergisi, 1(3), 58-73.

Oğuzkan, A. F. (2001a). Çocuk edebiyatı. Ankara: Anı Yayıncılık.

Oğuzkan, A. F. (2001b). Yerli ve yabancı yazarlardan örneklerle çocuk edebiyatı. Ankara: Anı Yayıncilık.

Oran, G. (2015). Yalvaç Ural'n çocuk kitaplarında değer eğitimi ve bu eserlerin Türkçe öğretimine katkısı. (Yayımlanmamış yüksek lisans tezi). Uşak Üniversitesi, Uşak.

Sever, S. (2012). Çocuk ve edebiyat. İzmir: Tudem.

Sever, S. (2013). Çocuk edebiyatı ve okuma kültürü. İzmir: Tudem.

Sever, S. (2018). Sanatsal uyaranlarla dil öğretimi. İzmir: Tudem.

Sever, S., Dilidüzgün, S., Neydim, N. ve Aslan, C. (2007). İlköğretimde çocuk edebiyatı. Eskiş̧ehir: Anadolu Üniversitesi Yayınları.

Sülün Özyar, G. (2012). Okuma becerisinin geliştirilmesi ve çocuğun dil-kavram gelişmesi bağlamında Yalvaç Ural'ın çocuk kitapları. (Yayımlanmamış yüksek lisans tezi). İstanbul Üniversitesi, İstanbul.

Şimşek, T. (2011). Kuramdan uygulamaya çocuk edebiyatı el kitabı. (1. Baskı). Ankara: Grafiker Yayınları.

Şirin, M. R. (2000). 99 soruda çocuk edebiyatı. İstanbul: Çocuk Vakfı Yayınları.

TDK. (2015). Türkçe sözlük. Ankara: Türk Dil Kurumu Yayınları.

Tekin, E. (2017). Süleyman Bulut'un çocuk kitaplarının çocuk edebiyatının temel ilkeleri açısından incelenmesi. (Yayımlanmamış yüksek lisans tezi). Balıkesir Üniversitesi, Balıkesir.

Yıldırım Bilgen, D. (2017). Çocuk edebiyatı alanındaki eserlerin söz varlığı ögelerine ilişkin karşlaştırmalı bir inceleme. International Journal of Languages' Education and Teaching, 5(3), 145-171.

Yıldız, M. ve Keş, Y. (2017). Yirmibirinci yüzyılın font tasarımlarında okunurluk üzerine çalışmalar. İdil Sanat ve Dil Dergisi, 6(38), 2791-2815. 